\title{
ON-FARM EVALUATION OF IMPROVED PATTERN THROUGH INCLUSION OF MUSTARD IN FALLOW PERIOD PRECEDING T. AUS-T. AMAN RICE CROPPING IN SYLHET REGION
}

\author{
*M.I. Nazrul ${ }^{1}$ \\ ${ }^{\mathbf{1}}$ PSO, Bangladesh Agricultural Research Institute (BARI), Gazipur-1701. \\ *Corresponding E-mail: mi_nazrul@yahoo.com
}

(Received: 13 December 2019, Accepted: 23 December 2019)

\begin{abstract}
Keywords: Rice based cropping pattern, land use efficiency, production efficiency, sustainableyield index, fallow land utilization
\end{abstract}

\begin{abstract}
The study was conducted at the farmer's field in Sylhet under AEZ 20 during three consecutive years 2016-17, 2017-18 and 2018-19 to determine the productivity and profitability of cropping patterns viz. IP: improved pattern (Mustard-T. Aus-T. Aman rice) by introducing high yielding varieties and improved management practices and FP: farmer's pattern (Fallow-T. Aus-T. Aman rice). The experiment was laid out in randomized complete block design with six dispersed replications. Results showed that the improved pattern with management practices provided 6.88 and $22.84 \%$ higher grain yield of T. Aus and T. Aman rice, respectively; also contributed higher mean rice equivalent yield $\left(9.44 \mathrm{t} \mathrm{ha}^{-1}\right)$ compared to farmer's pattern. Sustainable yield index $(0.36)$, production efficiency $\left(39.75 \mathrm{~kg} \mathrm{ha}^{-1} \mathrm{day}^{-1}\right)$, and land use efficiency $(75.98 \%)$ were maximum in Mustard-T. Aus- T. Aman rice cropping system on an average. Similarly, the highest mean gross margin (Tk.1,12,425 $\mathrm{ha}^{-1}$ ) with benefit cost ratio (2.13) was obtained from improved pattern. Three years results revealed that $24 \%$ extra cost provides an ample scope of considerable improvement of the productivity with the inclusion of Mustard before T. Aus rice in improved pattern.
\end{abstract}

\section{Introduction}

In Sylhet region, mainly Fallow - T. Aus - T. Aman rice cropping pattern is widely followed by farmers under rainfed condition. Transplantation of Aus rice is being dependent on rainfall, which sown during early monsoon (early May). This delayed transplantation of T. Aus rice that causes late cultivation and harvesting of $\mathrm{T}$. Aman rice, which hampered timely cultivation of rabi crops. The soils under these cropping pattern areas are generally heavy silty clay loams to clays and the top soil quickly becomes dry and hard after the harvest of T. Aman rice. In Eastern Surma Kushiara Floodplain of Sylhet region, a vast area remains fallow for a long time after the harvest of T. Aman rice due to moisture stress up to next season for cultivation of T. Aus rice following the existing cropping pattern (Fallow-T. Aus-T. Aman rice). However, the yields of rice are very low compared to other regions of the country.

Generally, rainfall starts in February and prevails up to November in each year that offers an excellent opportunity for the production of short duration pulse and oilseed crops before T. Aus rice. Shaheb etal.(2012) reported that mustard varieties can be grown well in fallow land of Sylhet where var. BARI Sarisha-14 and BARI Sarisha-17 could be more suitable and produced higher seed yield. To enhance the crop production through utilization of fallow land in Sylhet region, the potato-rice and chickpearice based cropping patterns have been developed (Nazrul et al., 2013; Nazrul and Shaheb, 2012; Shaheb et al., 2011). 
A number of reports on different cropping pattern are available in Bangladesh that an additional crop could be introduced without much changes or replacing the existing ones for considerable increases of productivity as well as profitability of the farmers (Azad et al. 1992; Khan et al., 2005 and Nazrul et al., 2013, Kamrozzaman et al., 2015). But, little effort has been made for on-farm evaluation of the improved technologies of Mustard-T. Aus-T. Aman rice cropping pattern in Sylhet area. The present study was therefore, initiated to determine productivity and economic feasibility of an improved package of technologies over the farmer's existing practices.

\section{Materials and Methods}

The study was carried out during three consecutive years 2016-17, 2017-18 and 2018-19 at farmer's field, Sylhet $\left(24^{\circ} 54^{\prime} \mathrm{N}\right.$ latitudes and $91^{\circ} 58^{\prime}$ E longitude) located in Agro Ecological Zone (AEZ)-20; under Eastern Surma Kushiyara Floodplain. This trial was conducted to derive the economic consequences of two cropping patterns viz. IP: improved pattern (Mustard-T. Aus rice-T. Aman rice) and FP: farmer's pattern (Fallow-T. Aus rice-T. Aman rice) through incorporation of high yielding varieties with improved management practices.

Annual monthly total rainfalls, along with maximum and minimum average temperatures during the study period are presented in Figure 1. The highest amount of average monthly rainfall occurred in June followed by July and May, whereas lowest amount of rainfall occurred in January followed by November and December. Rainfall increases gradually from the month of January to June and then decreases. The crops received 4295, 5045 and $3575 \mathrm{~mm}$ total rainfall during crop season of 2016-17, 2017-18 and 2018-19, respectively.

The monthly maximum air temperature of $35.80,37.00$ and $38.30^{\circ} \mathrm{C}$ and minimum of $10.30,10.30$ and $8.00^{\circ} \mathrm{C}$ during the crop season of 2016-17, 2017-18 and 2018-19, respectively. The soil was clay loam with low organic matter content (1.63\%) and soil $\mathrm{pH}$ was ranged 4.1-5.63 acidic in nature. The initial status of N (0.07\%), P (7.59 $\mu \mathrm{g} / \mathrm{soil}), \mathrm{K}(0.18 \mathrm{meq} / 100 \mathrm{~g}$ soil), S (10.80 $\mu \mathrm{g} / \mathrm{soil}), \mathrm{B}(0.34 \mu \mathrm{g} / \mathrm{soil})$ and $\mathrm{Zn}(1.27 \mu \mathrm{g} / \mathrm{soil})$ was very low, low, low, low, medium and medium, respectively. The trial was laid out in randomized complete block design with six dispersed replications. Two plots of $500 \mathrm{~m}^{2}$ were selected for each replication. One plot was under the improved pattern and the other farmer's pattern.

In the improved pattern, mustard var. BARI Sarisha-14 was introduced against fallow period. T. Aus rice var. BRRI dhan65 and T. Aman rice var. BRRI dhan57 was introduced instead of BR-26 and BRRI dhan33, respectively. The agronomic parameters and cultural operation for crop production under improved and farmer's practices are presented in Table 1. All field operation and management practices of both farmer's and improved pattern were closely monitored and the data were recorded for agro-economic performance. The differences between mean was compared by t-test.

Agronomic performance viz. land use efficiency, production efficiency, rice equivalent yield and sustainable yield index of cropping patterns were calculated. Land use efficiency is worked out by taking total duration of individual crop in a sequence divided by 365 days (Tomer and Tiwari, 1990). It is calculated by following formula:

$$
\text { Land use efficiency }=\frac{\mathrm{d}_{1}+\mathrm{d}_{2}+\mathrm{d}_{3}}{365} \times 100
$$

Where $d_{1}, d_{2}$ and $d_{3}$ the duration of first, secondand third crops of the pattern.

Production efficiency: Production efficiency values in terms of $\mathrm{Kg} \mathrm{ha}^{-1} \mathrm{day}^{-1}$ were calculated by total production in a cropping sequence divided by total duration of crops in that sequence (Tomer and Tiwari. 1990).

$$
\text { Production efficiency }=\frac{\mathrm{Y}_{1}+\mathrm{Y}_{2}+\mathrm{Y}_{3}}{\mathrm{~d}_{1}+\mathrm{d}_{2}+\mathrm{d}_{3}}\left(\mathrm{Kg} \mathrm{ha}^{-1} \text { day }^{-1}\right)
$$


Where, $Y_{1}$ : Yield of first crop; and $d_{1}$ : Duration of firstcrop of the pattern; $Y_{2}$ : Yield of secondcrop and $d_{2}$ : Duration of second crop of the pattern; $Y_{3}$ : Yield of third crop and $d_{3}$ : Duration of third crop of the pattern.

Sustainable Yield index (SYI): The yield data from two different cropping systems was processed and interpreted in terms of SYI. The SYI of individual treatment in each year of experimentation was calculated following the equation suggested by Singh et al. (1990).

$$
\text { Sustainable yield index }=\frac{\left(\mathrm{Y}_{\mathrm{t}}-\sigma\right)}{\mathrm{Y}_{\mathrm{m}}}
$$

Where, $\mathrm{Y}_{\mathrm{t}}$ is mean yield of respective treatment, $\sigma$ is the standard deviation (SD) and $\mathrm{Ym}$ is the maximum yield obtained under a set of management practices in any of the treatment and any of year in a given experiment.It indicates that sustainability in production over a period of time even though crop has high yields may or may not give sustainable yield index. Sustainability depends upon variation in the yield during crop period; if during the initial period yield is very low and hereafterit reached very high, as here variation is more from starting period to last, there is more yield but less sustainability and if crop yield variation is less from the beginning to the end there may be higher or lower yield but SYI would be higher.

\section{Rice equivalent yield:}

For comparison between crop sequences, the yield of all crops was converted into rice equivalent yield (REY) on the basis of prevailing market price of individual crop (Verma and Modgal, 1983).

$$
\text { Rice equivalent yield }\left(\mathrm{t} \mathrm{ha}^{-1}\right)=\frac{\text { Yield of individual crop x Market price of that crop }}{\text { Market price of rice }}
$$

The economic indices like gross and net returns and benefit cost ratio were also calculated on the basis of prevailing market price of the produces. For economic evaluation of two different cropping sequences averaged data of two crop cycles were used. The gross cost of cultivation of different crops was calculated on the basis of different operations performed and materials used for raising the crops. Benefit cost ratio (BCR) was also calculated by the following formula:

$$
\text { Benefit Cost Ratio }(\mathrm{BCR})=\frac{\text { Gross return }\left(\mathrm{Tk} . \mathrm{ha}^{-1}\right)}{\text { Total }(\text { variable }) \text { cost of cultivation }\left(\mathrm{Tk} . \mathrm{ha}^{-1}\right)}
$$




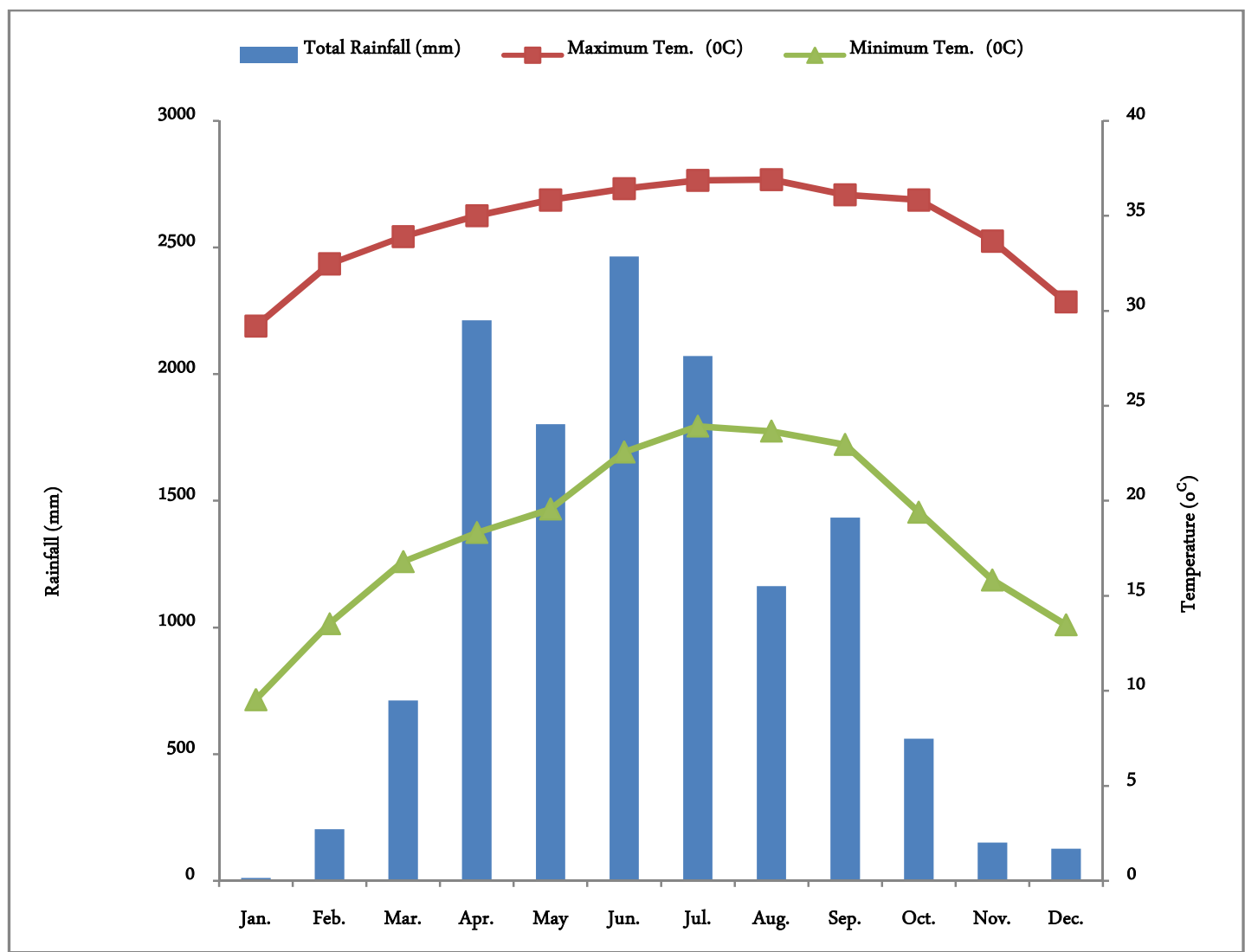

Fig.1. Average of three years monthly total rainfall (mm), maximum and minimum air temperatures during study period (Source: Metrological Department, Sylhet).

\section{Results and Discussion}

Yield of rice and mustard: In rice, the average yield of T. Aus and T. Aman was varied from 3.20 $4.43 \mathrm{t} \mathrm{ha}^{-1}$. In mustard, the variety BARI Sarisha-14 was produced $1.19 \mathrm{t} \mathrm{ha}^{-1}$ of seed yield in $\mathrm{CP}_{2}$ whereas lands remain fallow in $\mathrm{CP}_{1}$ at that period. The variety of $\mathrm{T}$. Aus and $\mathrm{T}$. Aman rice was given higher grain yields under the pattern $\mathrm{CP}_{2}$ it might be due to use of improved rice variety. The highest average yield of T. Aus $\left(3.43 \mathrm{tha}^{-1}\right)$ and T. Aman $\left(4.40 \mathrm{tha}^{-1}\right)$ rice was provided by $\mathrm{CP}_{2}$ (Table 1$)$.

T. Aman rice equivalent yield: The total productivity of the cropping sequence was ascertained by the rice equivalent yield (REY) it was calculated from the yields of component crops. REY was varied under different cropping sequence. In average of two years revealed that the highest REY $\left(9.37 \mathrm{tha}^{-1}\right)$ was recorded from $\mathrm{CP}_{2}$ as compared to $\mathrm{CP}_{1}\left(6.46 \mathrm{t} \mathrm{ha}^{-1}\right)$. Inclusion of mustard and modern variety of $\mathrm{T}$. Aus and T. Aman rice in $\mathrm{CP}_{2}$ increased REY $45.00 \%$ as compared to $\mathrm{CP}_{1}$. 
Table 1. Agronomic practices of improved (Mustard T. Aus-T. Aman rice) and farmer's existing (Fallow-T. Aus-T. Aman rice) cropping patterns during 2016-19

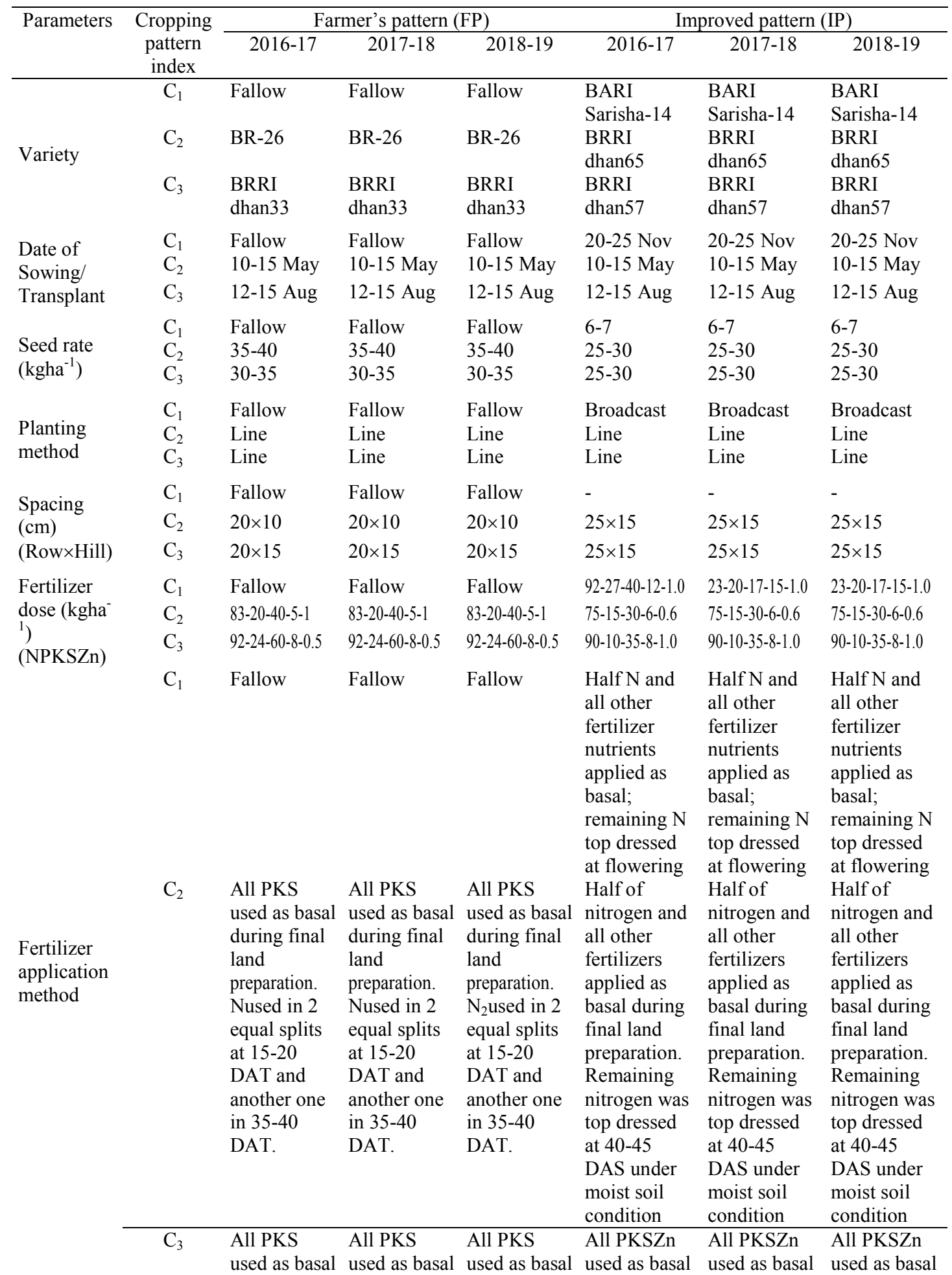




\begin{tabular}{|c|c|c|c|c|c|c|c|}
\hline \multirow[t]{3}{*}{ Parameters } & \multirow{3}{*}{$\begin{array}{l}\text { Cropping } \\
\text { pattern } \\
\text { index }\end{array}$} & \multicolumn{3}{|c|}{ Farmer's pattern (FP) } & \multicolumn{3}{|c|}{ Improved pattern (IP) } \\
\hline & & $2016-17$ & $2017-18$ & 2018-19 & $2016-17$ & $2017-18$ & 2018-19 \\
\hline & & $\begin{array}{l}\text { during final } \\
\text { land } \\
\text { preparation. } \\
\text { Nused in } 2 \\
\text { equal splits } \\
\text { at } 15-20 \\
\text { DAT and } \\
\text { another one } \\
\text { in } 35-40 \\
\text { DAT. }\end{array}$ & $\begin{array}{l}\text { during final } \\
\text { land } \\
\text { preparation. } \\
\text { Nused in } 2 \\
\text { equal splits } \\
\text { at } 15-20 \\
\text { DAT and } \\
\text { another one } \\
\text { in } 35-40 \\
\text { DAT. }\end{array}$ & $\begin{array}{l}\text { during final } \\
\text { land } \\
\text { preparation. } \\
\text { Nused in } 2 \\
\text { equal splits } \\
\text { at } 15-20 \\
\text { DAT and } \\
\text { another one } \\
\text { in } 35-40 \\
\text { DAT. }\end{array}$ & $\begin{array}{l}\text { and } \mathrm{N} \text { used } \\
\text { in } 3 \text { equal } \\
\text { splits, the } \\
\text { first one after } \\
\text { 15DAT, } \\
\text { second one at } \\
\text { 35-40 DAT } \\
\text { and third one } \\
\text { at 5-7 days } \\
\text { beforepanicle } \\
\text { initiation }\end{array}$ & $\begin{array}{l}\text { and Nused in } \\
3 \text { equal } \\
\text { splits, the } \\
\text { first one after } \\
15 \text { DAT, } \\
\text { second one at } \\
35-40 \text { DAT } \\
\text { and third one } \\
\text { at 5-7 days } \\
\text { before } \\
\text { panicle } \\
\text { initiation }\end{array}$ & $\begin{array}{l}\text { and } N \text { used } \\
\text { in } 3 \text { equal } \\
\text { splits, the } \\
\text { first one after } \\
\text { 15DAT, } \\
\text { second one at } \\
35-40 \text { DAT } \\
\text { and third one } \\
\text { at } 5-7 \text { days } \\
\text { before } \\
\text { panicle } \\
\text { initiation }\end{array}$ \\
\hline \multirow{3}{*}{$\begin{array}{l}\text { Weeding } \\
\text { (no.) }\end{array}$} & $\mathrm{C}_{1}$ & Fallow & Fallow & Fallow & 0 & 0 & 0 \\
\hline & $\mathrm{C}_{2}$ & 2 & 2 & 2 & 2 & 2 & 2 \\
\hline & $\mathrm{C}_{3}$ & 1 & 1 & 1 & 2 & 2 & 2 \\
\hline \multirow{3}{*}{$\begin{array}{l}\text { Irrigation/R } \\
\text { ainfed }\end{array}$} & $\mathrm{C}_{1}$ & Fallow & Fallow & Fallow & Rainfed & Rainfed & Rainfed \\
\hline & $\mathrm{C}_{2}$ & Rainfed & Rainfed & Rainfed & Rainfed & Rainfed & Rainfed \\
\hline & $\mathrm{C}_{3}$ & Rainfed & Rainfed & Rainfed & Rainfed & Rainfed & Rainfed \\
\hline \multirow{2}{*}{$\begin{array}{l}\text { Insect-pest } \\
\text { control }\end{array}$} & $\begin{array}{l}\mathrm{C}_{1} \\
\mathrm{C}_{2}\end{array}$ & $\begin{array}{l}\text { Fallow } \\
\text { Chemical }\end{array}$ & $\begin{array}{l}\text { Fallow } \\
\text { Chemical }\end{array}$ & $\begin{array}{l}\text { Fallow } \\
\text { Chemical }\end{array}$ & $\begin{array}{l}\text { IPM } \\
\text { IPM }\end{array}$ & $\begin{array}{l}\text { IPM } \\
\text { IPM }\end{array}$ & $\begin{array}{l}\text { IPM } \\
\text { IPM }\end{array}$ \\
\hline & $\mathrm{C}_{3}$ & Chemical & Chemical & Chemical & IPM & IPM & IPM \\
\hline $\begin{array}{l}\text { Harvest } \\
\text { time (date) }\end{array}$ & $\begin{array}{l}\mathrm{C}_{1} \\
\mathrm{C}_{2} \\
\mathrm{C}_{3}\end{array}$ & $\begin{array}{l}\text { Fallow } \\
10-15 \text { Aug } \\
10-16 \text { Dec }\end{array}$ & $\begin{array}{l}\text { Fallow } \\
10-15 \text { Aug } \\
10-16 \text { Dec }\end{array}$ & $\begin{array}{l}\text { Fallow } \\
\text { 10-15 Aug } \\
\text { 10-15 Dec }\end{array}$ & $\begin{array}{l}\text { 20-28 Feb. } \\
\text { 28-30 July } \\
\text { 15-20 Nov }\end{array}$ & $\begin{array}{l}\text { 20-28 Feb. } \\
\text { 28-30 July } \\
\text { 15-20 Nov }\end{array}$ & $\begin{array}{l}\text { 20-28 Feb. } \\
\text { 28-30 July } \\
\text { 15-20 Nov }\end{array}$ \\
\hline $\begin{array}{l}\text { Field } \\
\text { duration } \\
\text { (days) }\end{array}$ & $\begin{array}{l}\mathrm{C}_{1} \\
\mathrm{C}_{2} \\
\mathrm{C}_{3} \\
\end{array}$ & $\begin{array}{l}\text { Fallow } \\
105-110 \\
112-115 \\
\end{array}$ & $\begin{array}{l}\text { Fallow } \\
105-110 \\
112-115 \\
\end{array}$ & $\begin{array}{l}\text { Fallow } \\
105-110 \\
105-115 \\
\end{array}$ & $\begin{array}{l}75-80 \\
95-100 \\
100-105 \\
\end{array}$ & $\begin{array}{l}75-80 \\
95-100 \\
100-105\end{array}$ & $\begin{array}{l}75-80 \\
95-100 \\
100-105\end{array}$ \\
\hline \multicolumn{2}{|c|}{ Total duration (days) } & $217-225$ & $217-225$ & $210-225$ & $270-285$ & $270-285$ & $270-285$ \\
\hline
\end{tabular}

$\mathrm{C}_{1}$ : Fallow/Mustard; $\mathrm{C}_{2}$ : T. Aus; $\mathrm{C}_{3}$ : T. Aman rice; IPM: integrated pest management

\section{Grain/Seed Yield of the Cropping Patterns}

Improved pattern took 270-285 days against 217-225 days due to inclusion of mustard the pattern. This indicates that mustard could easily be grown or fitted before T. Aus rice. The grain yield of rice was significantly higher in the improved pattern as compared to farmers existing pattern during individual years and mean data (Table 2). Variation in the yield of rice as evident in the improved pattern might be due to change of variety with improved production technologies. Similar results were also obtained by Nazrul et al. (2013) and Khan et al. (2005) in case of rice based cropping sequences. In all the years, farmers' pattern gave lower grain yield of rice due to imbalance use of fertilizers and traditional management practices. On the contrary, the yield of T. Aus and T. Aman rice was higher in improved pattern due to insertion of high yielding modern rice varieties. During experimentations in year of 2017-18, the rice bug was found in T. Aman rice field at panicle formation to flowering. But it was successfully controlled by applying chlorpyrifos insecticide (Dursban 20 EC @ $20 \mathrm{ml}$ in 10 liters of water for 5 decimal areas). The rice variety, BRRI dhan65 and BRRI dhan57 in improved pattern performed better than BR-26 and BRRI dhan33 in farmers' practices due to higher yield potential of the variety.

\section{By-product yield of the cropping patterns}

The improved cropping pattern produced higher amount of total by-product yield $\left(9.06\right.$ tha $\left.^{-1}\right)$ than the by-product yield of the crops $\left(8.74 \mathrm{t} \mathrm{ha}^{-1}\right)$ of the farmers' pattern (Table 2). The by-product yield of improved pattern was higher due to introduction and change of variety with improved technologies for the component crops. In all the years, mustard contributed valuable by-product. On the contrary, 
farmers are not able to sale by-product (rice straw) in the local market; whereas, the by-product of mustard has been used as fuel by the farmers.

Table 2. Productivity of improved (Mustard-T. Aus-T. Aman) and farmer's existing (Fallow-T. Aus-T. Aman) cropping patterns during 2016-19

\begin{tabular}{cccccccc}
\hline \multirow{2}{*}{ Years } & Cropping & \multicolumn{3}{c}{ Seed/Grain yield $\left(\mathrm{t} \mathrm{ha}^{-1}\right)$} & \multicolumn{3}{c}{ By product yield $\left(\mathrm{t} \mathrm{ha}^{-1}\right)$} \\
\cline { 3 - 8 } & patterns & Fallow/Mustard & T. Aus & T. Aman & Fallow/Mustard & T. Aus & T. Aman \\
\hline \multirow{2}{*}{$2016-17$} & FP & - & 3.20 & 3.64 & - & 4.25 & 4.68 \\
& IP & 1.19 & 3.42 & 4.43 & 3.19 & 4.32 & 4.75 \\
\multirow{2}{*}{$2017-18$} & FP & - & 3.17 & 3.60 & - & 4.20 & 4.56 \\
& IP & 0.96 & 3.43 & 4.36 & 3.00 & 4.35 & 4.72 \\
\multirow{2}{*}{$2018-19$} & FP & - & 3.22 & 3.54 & - & 4.14 & 4.35 \\
& IP & 1.20 & 3.40 & 4.44 & 3.21 & 4.35 & 4.70 \\
\multirow{2}{*}{ Mean } & FP & - & 3.20 & 3.59 & - & 4.21 & 4.53 \\
& IP & 1.12 & 3.42 & 4.41 & 3.13 & 4.34 & 4.72 \\
\hline
\end{tabular}

\section{Rice equivalent yield}

The component crops of Mustard-T. Aus-T. Aman rice cropping pattern under improved practices (IP) gave higher T. Aman rice equivalent yields against grain yield as well as by-product in all the years. The mean rice equivalent yield under improved cropping pattern also produced higher rice equivalent yield over farmers' traditional cropping pattern (Table 3). On an average, the T. Aman rice equivalent yield in improved pattern increased $47 \%$ over the crops under farmers' practices. Inclusion of high yielding new crop varieties with improved management practices increased the higher T. Aman rice equivalent yield. It was also due to higher price of components crops in the improved pattern. Lower rice equivalent yield was obtained in the farmers' pattern probably due to variety and traditional management practices.

\section{Production efficiency}

Maximum production efficiency was obtained from improved pattern during individual years and also means data (Table 3). The higher production efficiency of improved cropping pattern might be due to inclusion of a new or modern varieties and management practices. In conversely, the lowest production efficiency was observed in farmers' pattern where crop remained in the field for shorter time and yields were also lower, leading to lower production per day. Mean production efficiency $\left(39.75 \mathrm{~kg} \mathrm{ha}^{-1} \mathrm{day}^{-1}\right)$ was higher in improved pattern and lower $\left(30.18 \mathrm{~kg} \mathrm{ha}^{-1} \mathrm{day}^{-1}\right)$ in farmers' pattern. Similar trend were noted by Nazrul et al. (2013) and Khan et al. (2005) in case of improved cropping sequences.

\section{Land use efficiency}

Land use efficiency is the effective use of land in a cropping year, which mostly depends on crop duration. The average land-use efficiency indicated that improved pattern used the land for $75.98 \%$ period of the year, whereas farmer's pattern used the land for $60.55 \%$ period of the year (Table 3 ). The land use efficiency was higher in improved pattern due to cultivation of mustard as additional crop in fallow period.

\section{Sustainable yield index}

The sustainable yield index (SYI) of farmer's and improved cropping pattern is presented in Table 3. The values of sustainable yield index as a measure of sustainability of the system which was high in the improved cropping system (0.34-0.37) over farmer's practices $(0.18)$. The results showed that between two different cropping systems Mustard-T. Aus-T. Aman rice recorded the highest mean SYI of 0.36 followed by Fallow-T. Aus-T. Aman rice (0.18). So, cropping system including mustard in fallow period and modern varieties of T. Aus and T. Aman rice recorded higher SYI compared to fallow-rice based crop sequences. The results are in agreement with the findings of Nazrul et al. (2017); Nazrul et 
al. (2013) and Ram et al. (2012). This indicated that improved pattern is therefore, more stable than farmer's pattern. Mustard is providing special advantage regarding utilization of mustard straw as fuel instead of cow dung.

Table 3. Rice equivalent yield, production efficiency, land use efficiency and sustainable yield index of improved and farmers patterns at farmer's field during 2016-19

\begin{tabular}{|c|c|c|c|c|c|}
\hline Years & $\begin{array}{l}\text { Cropping } \\
\text { patterns }\end{array}$ & $\begin{array}{l}\text { Rice (T. Aman) } \\
\text { equivalent yield } \\
\left(\text { tha }^{-1}\right)\end{array}$ & $\begin{array}{c}\text { Production } \\
\text { efficiency } \\
\left(\mathrm{Kg} \mathrm{ha}^{-1} \text { day }^{-1}\right) \\
\end{array}$ & $\begin{array}{l}\text { Land use } \\
\text { efficiency } \\
(\%)\end{array}$ & $\begin{array}{l}\text { Sustainable yield } \\
\text { index } \\
\text { (SYI) }\end{array}$ \\
\hline \multirow{2}{*}{ 2016-17 } & FP & 6.48 & 30.40 & 59.45 & 0.18 \\
\hline & IP & 9.59 & 40.18 & 73.97 & 0.37 \\
\hline \multirow{2}{*}{ 2017-18 } & FP & 6.42 & 30.09 & 60.55 & 0.18 \\
\hline & IP & 9.12 & 38.89 & 75.90 & 0.34 \\
\hline \multirow{2}{*}{ 2018-19 } & FP & 6.40 & 30.04 & 61.64 & 0.18 \\
\hline & IP & 9.59 & 40.18 & 78.08 & 0.37 \\
\hline \multirow{2}{*}{ Mean } & FP & 6.43 & 30.18 & 60.55 & 0.18 \\
\hline & IP & 9.43 & 39.75 & 75.98 & 0.36 \\
\hline
\end{tabular}

\section{Economic}

Between two crop sequences, the improved cropping pattern showed its superiority over farmers' existing pattern during three consecutive years of cropping season. On an average, gross return of the improved pattern was Tk. $212175 \mathrm{ha}^{-1}$ which was more than $47 \%$ higher than farmers' pattern of Tk. $144675 \mathrm{ha}^{-1}$ (Table 4). The production cost of the improved pattern (Tk. $99750 \mathrm{ha}^{-1}$ ) was higher than farmers' pattern (Tk. $80761 \mathrm{ha}^{-1}$ ) due to introduction of mustard in fallow period, cost of fertilizer and other inputs. The gross margin was substantially higher in the improved pattern (Tk. $112425 \mathrm{ha}^{-1}$ ) than farmers' pattern (Tk. $63914 \mathrm{ha}^{-1}$ ). Inclusion of mustard and improved varieties of rice in these cropping systems, increasing the system productivity fetched higher market price; thereby, increasing the gross margin. The $76 \%$ additional gross margin was achieved by adding $24 \%$ additional cost in the improved pattern. Returns per Taka invested were highest for mustard-T. Aus-T. Aman rice (2.13) over the farmers' pattern (1.79).

Table 4. Cost benefit analysis of improved and farmer's existing cropping pattern at farmer's field (average of three years).

\begin{tabular}{lccccc}
\hline Years & $\begin{array}{c}\text { Cropping } \\
\text { patterns }\end{array}$ & $\begin{array}{c}\text { Gross return } \\
\left(\text { Tk. ha }^{-1}\right)\end{array}$ & $\begin{array}{c}\text { Cost of cultivation } \\
\left(\mathrm{Tk}^{-1} \mathrm{ha}^{-1}\right)\end{array}$ & $\begin{array}{c}\text { Gross margin } \\
\left(\mathrm{Tk}^{-1} \mathrm{ha}^{-1}\right)\end{array}$ & BCR \\
\hline \multirow{2}{*}{$2016-17$} & FP & 145800 & 80761 & 65039 & 1.81 \\
& IP & 215775 & 99750 & 116025 & 2.16 \\
\multirow{2}{*}{$2017-18$} & FP & 144450 & 80761 & 63689 & 1.79 \\
& IP & 205200 & 99750 & 105450 & 2.06 \\
\multirow{2}{*}{$2018-19$} & FP & 144000 & 80761 & 63239 & 1.78 \\
& IP & 215775 & 99750 & 116025 & 2.16 \\
\hline \multirow{2}{*}{ Mean } & FP & 144675 & 80761 & 63914 & 1.79 \\
& IP & 212175 & 99750 & 112425 & 2.13 \\
\hline
\end{tabular}

Note- FP: Farmer's pattern, IP: Improved patter; the costs (Tk. $\left.\mathrm{kg}^{-1}\right)$ : rice seed (32.00), mustard seed (90.00), and, urea (20.00), TSP (22.00) and MoP (15.00);

Among field operations, the cost of plowing was taken as Tk. 10 decimal ${ }^{-1}$, labour cost of Tk. $350 \mathrm{~m}^{-1}$ day $^{-1}$. Gross returns included income from sale of main and by-products $\left(\mathrm{Tk} . \mathrm{ka}^{-1}\right.$ ) of all crops; T. aus rice (20.00), T. aman rice (22.50), mustard (40.00), rice straw (0.50), mustard stover (1.00). 


\section{Conclusion}

Three years study revealed that Mustard-T. Aus-T. Aman rice cropping system is more productive, sustainable and remunerative for medium high land under Eastern Surma Kushiyara Floodplain (AEZ 20). So, farmers of commanding area could follow Mustard (var. BARI Sarisha-14)-T. Aus (var. BRRI dhan65)-T. Aman rice (var. BRRI dhan57) cropping pattern for higher productivity and profitability as well as mustard straw can be utilized as fuel instead of cow dung.

\section{Acknowledgements}

Authors are gratefully acknowledged Bangladesh Agricultural Research Institute, Gazipur and Metrological Department, Sylhet for providing financial help and logistic support and weather data, respectively. Thanks to others who contributed in editing and compiling the manuscript.

\section{References}

Azad, A.K., F.A.H. Talukdar, M.A. Wahhab and M.A. Khan. 1992. Progress and prospect of jute based cropping systems research in Bangladesh. Proc. Expert Cons. Jute and Kenaf Improvement: pp.244-267.

Kamrozzaman, M.M., M.A.H. Khan, S. Ahmed and A.F.M.R. Quddus. 2015. On-farm evaluation of production potential and economics of Wheat-Jute-T. aman rice-based cropping system. J. Bangladesh Agril. Univ. 13(1): 93-100.

Khan, M.A.H., M.A. Quayyum, M.I. Nazrul, N. Sultana and M.R.A. Mollah. 2005. On-farm evaluation of production potential and economics of mustard-rice based improved cropping system. J. Socio. Res. Dev. 2(1): 37-42.

Nazrul, M.I. and M.R. Shaheb. 2012. Potato-T. aus-T. aman: An improve and sustainable cropping pattern for fallow land utilization of Sylhet. Published by On-Farm Research Division, Bangladesh Agricultural Research Institute (BARI), Sylhet-3100, p.24.

Nazrul, M.I., M.K. Hasan and M.R.I. Mondal. 2017. Production potential and economics of mung bean in rice based cropping pattern in Sylhet region under AEZ 20. Bangladesh J. Agril. Res. 42(3):413424.

Nazrul, M.I., M.R. Shaheb, M.A.H. Khan and A.S.M.M.R. Khan. 2013. On-farm evaluation of production potential and economic returns of potato-rice based improved cropping system. Bangladesh J. Agril. Res. 16(2): 41-50.

Ram, A.J., R.A. Dungrani, M.K. Arvadia and K.L. Sahrawat. 2012. Diversification of rice (Oryza sativa L.) based cropping systems for higher productivity, resource-use efficiency and economic returns in South Gujarat of India. Archives Agron. Soil Sci. 58(6): 561-572.

Shaheb, M.R, M.I. Nazrul, A.K. Chowdhury, M.M.R Sarker, A.S.M. Khan and J.U. Sarker. 2011. Chick pea-T. aus- T. aman: A prosperous and improved cropping pattern for Sylhet region. Published by On- Farm Research Division, Bangladesh Agricultural Research Institute (BARI), Sylhet-3100. p.13.

Shaheb, M.R., M.I. Nazrul and M. Ali.2012. Performance of Mustard varieties for fallow land utilization in Sylhet region. Bangladesh Agron. J. 15(2): 47-52.

Singh, R.P., S.K. Das, U.M.B. Rao andM.N. Reddy. 1990. Towards Sustainable Dryland Agriculture Practices, Bulletin, CRIDA, Hyderabad, India.

Tomer, S.S and A.S. Tiwari. 1990. Production potential and economics of different crop sequences. Indian J. Agron. 35(1, 2): 30-35.

Verma, S.P and S.C. Modgal. 1983. Production potential and economics of fertilizer application as resources constraints in maize, wheat crop sequence. Himachal J. Agric. Res. 9(2): 89-92. 